\title{
Sastra Satire Kitab Yunus: Analisis Naratif Prolog dan Epilog Kitab Yunus
}

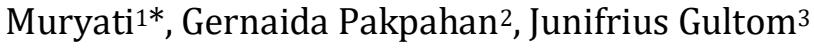

1,2,3Sekolah Tinggi Teologi Bethel Indonesia, Jakarta

*correspondence email: muryatisetianto28@gmail.com

\begin{abstract}
The anomaly of Jonah's attitude in rejecting God's call (Jonah 1) and his anger at Nineveh's conversion caused various opinions on the genre of his book. This encourages the need to produce new findings to narrow the view of experts by placing the book of Jonah as satire literature. The purpose of this research is to describe the satire elements contained in the prologue and epilogue of the book of Jonah. The method used in this research is a narrative approach using a modified method that departs from the four narrative elements namely the narrator, character (characterization), point of view, and storyline then combined with some elements of general interpretation in it. through the narrative analysis method the researcher sees the text as a "mirror" that projects a certain picture, namely the world of narratives that provides benefits to explore the forms and elements of the prologue and epilogical satire texts of the book of Jonah. The results showed that Irony underlies all elements of satire spread in articles 1 and 4. Researchers classify the elements of irony as personification, repetition, hyperbole, sarcasm, paronomosia and parody. These characteristics indicate Jonah 1 and 4 are narratives containing satire. The implication of the teaching of the church by referring to the didactic values in the satire of the story of Satire Jonah can be used as a reference for learning the truth of God's Word.
\end{abstract}

Keywords: literature; satire; jonah; prologue; epilogue; narration; irony

Abstrak: Anomali sikap Yunus dalam menolak panggilan Tuhan (Yunus 1) dan kemarahannya pada pertobatan Niniwe menimbulkan beragam pendapat pada genre kitabnya. Hal ini mendorong adanya kebutuhan untuk menghasilkan temuan baru guna mempersempit pandangan para pakar dengan menempatkan kitab Yunus sebagai sastra satire. Tujuan dilakukan penelitian ini adalah untuk mendeskripsikan unsur satire yang terdapat dalam prolog dan epilog kitab Yunus. Metode yang digunakan dalam penelitian ini adalah pendekatan naratif menggunakan modifikasi metode yang berangkat dari empat unsur narasi yaitu narator, karakter (penokohan), sudut pandang, dan alur cerita lalu dikombinasikan dengan beberapa elemen penafsiran umum di dalamnya. melalui metode analisis naratif peneliti melihat teks sebagai sebuah "cermin" yang memproyeksikan gambaran tertentu, yaitu dunia narasi yang memberikan manfaat untuk mengeksplorasi bentuk dan unsur satire teks prolog dan epilog dari kitab Yunus. Hasil penelitian menunjukkan bahwa Ironi mendasari semua unsur satire yang tersebar di pasal 1 dan 4 . Peneliti mengelompokkan unsur ironi adalah personifikasi, repetisi, hiperbola, sarkasme, paronomosia dan parodi. Karakteristik ini mengindikasikan Yunus 1 dan 4 adalah narasi yang mengandung satire. Implikasinya terhadap pengajaran gereja dengan merujuk pada nilai-nilai didaktis dalam satire kisah Satire Yunus dapat dijadikan rujukan untuk mempelajari kebenaran Firman Tuhan.

Kata kunci: Sastra; Satire; Yunus; Prolog; Epilog; Narasi; Ironi 


\section{PENDAHULUAN}

Kitab Yunus memiliki keunikan yang menjadi daya tarik tersendiri jika dibandingkan dengan kitab-kitab Perjanjian Lama, khususnya kitab para nabi. Kitab ini menampilkan seorang nabi Israel, namun tidak memenuhi peran yang diharapkan dari seorang nabi. Tokoh Yunus menunjukkan perilaku yang tak lazim ketika menolak panggilan Tuhan (Yunus 1) dan kemarahannya pada pertobatan Niniwe (Yunus 4). Perilaku marah dalam diri Yunus menunjukkan dia sebagai orang temperamen. ${ }^{1}$ Pada umumnya kitab para nabi berisikan nubuat dan tidak fokus kepada pribadi sang nabi. Anomali kitab Yunus ini menjadi polemik munculnya pelbagai persoalan dan sekaligus menjadi fenomena yang menarik untuk dikaji dari kitab Yunus, antara lain: persoalan genre kitab. Genre kitab Yunus menjadi salah satu elemen yang paling diperdebatkan sejumlah pakar, di antaranya:

Pertama, kisah Yunus adalah narasi. ${ }^{2}$ Dasarnya kecenderungan kitab-kitab para nabi adalah memberikan porsi yang besar di dalam teksnya untuk menyampaikan maklumat Ilahi yang ditujukan kepada publik. Keadaan ini tidak terjadi dalam kitab Yunus. Kedua, kisah Yunus adalah fiksi dengan menggunakan nama seperti: legenda, novella, cerita pendek, atau cerita rakyat, untuk menekankan aspek non-historis petualangan Yunus. Limburg berpendapat bahwa genre kitab Yunus dapat digambarkan sebagai kisah fiktif yang dikembangkan di sekitar tokoh historis untuk tujuan-tujuan yang disengaja. ${ }^{3}$ Ketiga, kitab Yunus yang berbentuk cerita, membuat para ahli cenderung menggunakan pendekatan literer dengan menempatkan kitab Yunus sebagai sebuah karya sastra satire. John Miles mengamati bahwa kitab Yunus itu merupakan cerita yang sarat dengan adegan parodi. ${ }^{4}$ David Marcus mengidentifikasi karakteristik satire dan menyatakan bahwa teks dapat diidentifikasi sebagai satire jika memiliki target yang merupakan objek serangan, baik secara langsung atau tidak langsung, dan memiliki lebih banyak atribut penting dari satire seperti ironi, ejekan, parodi, dan fitur retoris. ${ }^{5}$ Steven L. McKenzie mengatakan bahwa kisah Yunus satire sebab penuh dengan humor, dibesar-besarkan, ironi dan olokolokan/ejekan. ${ }^{6}$

Sementara, Mark mengamati kitab Yunus itu sarat dengan humor yang ditunjukkan oleh mechanical behavior tokohnya, Yunus. Mechanical behavior menjadi kunci utama untuk mengategorikan kitab Yunus sebagai satire yang didasarkan pada beberapa unsur berikut: parodi, hiperbola, surealisme, permainan kata dan ironi. ${ }^{7}$ Unsur-unsur tersebut juga dijelaskan oleh beberapa penelitian terdahulu. Misalnya Robert Justin Harkins yang menjelaskan bahwa kisah Yunus yang berbentuk cerita singkat mengenai perjalanan

\footnotetext{
${ }^{1}$ Muryati and others, 'Strategi Mengatasi Kemarahan Melalui Perumpamaan Berdasarkan Yunus 4', Jurnal Teologi Gracia Deo, 3.1 (2020), 14-23.

${ }^{2}$ Ben Ehud Zvi, 'Jonah', in The Jewish Study Bible, ed. by Berlin Adele and Marc Zvi Brettler (Oxford: Oxford University Press, 2004), 198.

${ }^{3}$ James Limburg, Jonah: A Commentary (Kentucky: Westminster/John Konx Press, 1993), 24.

${ }^{4}$ John A. Miles Jr., 'Laughing at the Bible: Jonah as Parody', in On Humor and Comic in the Hebrew Bible (Sheffield: Almond Press, 1990).

${ }^{5}$ David Marcus, From Balaam to Jonah-Anti-Prophetic Satire in the Hebrew Bible (Atlanta: Scholar Press, 1995), 9.

${ }^{6}$ Steven L. McKenzie and Stephen R. Haynes, To Each Its Own Meaning: An Introduction to Biblical Criticisms and Their Application (Louisville: Westminster/John Konx Press, 1999), 2.

${ }^{7}$ Mark S. Haughwout, Humor in the Bible (Hebrew University Jerusalem, 2010), 3.
} 
seorang nabi terhadap panggilan Tuhan menyisakan banyak persoalan terkait dengan genre. Harkins menggambarkan sebagai tokoh yang bersifat antihero, dalam artian Yunus ialah aktor sosial yang gagal, seorang nabi Israel yang gagal, dan Kitab Yunus juga menjelaskan perjalanan yang $\operatorname{salah}^{8}$ DJuharto memfokuskan penelitiannya terhadap panggilan Yunus dan pelajaran dari kegagalan Yunus memahami kedaulatan Allah yang universal kepada manusia pilihan-Nya. ${ }^{9}$ Juliana M Claasen menemukan bahwa terdapat unsur komedi dalam Kitab Yunus, yang didasarkan atas konsep tragic laughter dari Jacqueline Bussie. Tragic Laughter sendiri memiliki tujuan untuk mengganggu sistem penindasan, sehingga berfungsi sebagai bentuk perlawanan dan protes dalam menghadapi penyimpangan efek trauma psikologi. Hal tersebut sebagaimana dijelaskan Claasen berada di dalam Kitab Yunus. ${ }^{10}$

Alyssa Walker menampilkan Yunus sebagai hamba Tuhan yang berkeinginan mati ketimbang melihat kota Niniwe berdiri kokoh. Dari pendekatan literer, Walker mengungkapkan bahwa seorang nabi Allah malah berkeinginan kuat akan terjadinya genosida bagi orang-orang Niniwe. ${ }^{11}$ Richard D. Patteson menjelaskan nabi-nabi Perjanjian Lama menggunakan satire tidak hanya sebatas sebagai seni sastra, namun juga digunakan untuk norma dan standar etika. ${ }^{12}$ Ian J. Vailancourt juga menjelaskan bahwa unsur mazmur dalam Kitab Yunus berkontribusi terhadap tema ironi. ${ }^{13}$ Untuk membedakan dengan penelitian sebelumnya, peneliti menggunakan metode naratif dalam menggali unsur-unsur satire kitab Yunus. Hal yang mendasari karena genre kitab Yunus adalah narasi.

Analisis naratif ini menggali bentuk dan karakteristik satire melalui narator, tokoh, plot dan sudut pandang. Satire sebagai bagian dari gaya retorik atau perangkat sastra yang digunakan penulis untuk mengekspos dan mengkritisi Yunus. Peneliti tidak menampik genre kitab Yunus yang beragam ini menjadi kendala untuk membaca, menafsirkan dan sekaligus menemukan pesan kitab. Hal ini mendorong adanya kebutuhan untuk menghasilkan temuan baru guna mempersempit pandangan para pakar terkait dengan kitab Yunus. Dengan merujuk pada satu genre yaitu menempatkan kitab Yunus sebagai sastra satire, diharapkan para pembaca memperoleh kemudahan dalam membaca, menafsirkan dan menemukan pesan kitab Yunus.

Alasan peneliti mengangkat prolog dan epilog kitab Yunus didasari dua alasan. Pertama, struktur prolog dan epilog kitab Yunus bergenre narasi. Hal ini didasari begitu kentalnya karakter narasi di kedua pasal ini. Komponen narasi seperti tokoh, narator, sudut pandang, dan plot terbaca di garis besar kitabnya yang mengisahkan kehidupan seorang

\footnotetext{
${ }^{8}$ Robert Justin Harkins, 'Jonah and The Prophetic Character' (Vanderblit University, 2010).

${ }^{9}$ Gumulya Djuharto, 'ANALISA PANGGILAN YUNUS DALAM KITAB YUNUS 1 : 1-17', Jurnal Theologi Aletheia, 16.6 (2014), 1-17.

${ }^{10}$ L. Juliana and M. Claassens, 'Rethinking Humour in the Book of Jonah: Tragic Laughter as Resistance in the Context of Trauma', Old Testament Essays, 28.3 (2015), 655-73 <https://doi.org/10.17159/2312-3621/2015/v28n3a6>.

${ }^{11}$ Alyssa Walker, 'Jonah' s Genocidal and Suicidal Attitude — and God's Rebuke *', KAIROS Evangelical Journal of Theology, 9.1 (2015), 7-30.

${ }^{12}$ Richard D. Patterson, 'Prophetic Satire As a Vehicle for Ethical Instruction', Journal of the Evangelical Theological Society, 50.1 (2007), 47-69.

${ }^{13}$ Ian J. Vaillancourt, 'The Pious Prayer of an Imperfect Prophet: The Psalm of Jonah in Its Narrative Context', Journal for the Evangelical Study of the Old Testament, 4.2 (2015).
} 
nabi yang bernama Yunus. Kedua, argumen lain yang memperkuat dikaitkan dengan hubungan sebab akibat dari cerita yang dimulai di Yunus 1 (prolog) dan berakhir di Yunus 4 (epilog). Di prolog menampilkan Yunus yang menolak panggilan Tuhan tanpa diberikan alasannya dan di bagian epilognya diberikan alasannya. Ini menjadi indikasi kuat ada kesinambungan ceritanya. Melalui kisah Yunus diperlihatkan Tuhan yang berbelas kasihan dan berdaulat penuh atas ciptaan-Nya.

Dari urgensi ini dapat dirumuskan sebuah permasalahan yaitu untuk menelusuri unsur-unsur satire yang terdapat dalam prolog dan epilog kitab Yunus. Tujuan dilakukan penelitian ini selain untuk mendeskripsikan unsur satire yang terdapat dalam prolog dan epilog kitab Yunus diharapkan juga berimplikasi menjadi pengajaran gereja terhadap Kitab Yunus yang masih terbilang jarang.

\section{METODE PENELITIAN}

Mengingat bahwa dalam penelitian ini kitab Yunus harus dilihat dalam perspektif analisis naratif, maka peneliti akan menggunakan modifikasi metode yang berangkat dari empat unsur narasi yaitu narator, karakter, sudut pandang, dan alur cerita ${ }^{14}$, lalu dikombinasikan dengan beberapa elemen penafsiran umum di dalamnya. ${ }^{15}$ Metode penafsiran penelitian ini tergambar pada diagram di bawah ini. Peneliti akan mendekati teks narasi dari prolog dan epilog kitab Yunus dengan akses analisis naratif yang terkonsentrasi pada empat elemen yaitu narator, karakter, sudut pandang, dan alur cerita. Tentunya peneliti tidak mengabaikan prinsip-prinsip penafsiran umum. Prinsip-prinsip penafsiran umum membantu mempertajam kedalaman analisis teksnya. Melalui informasi dan data dari konteks kesusastraan, latar belakang sejarah dan budaya, makna kata, dan tata bahasa maka pendeskripsian dari narator, penokohan, sudut pandang, dan alur cerita semakin jelas.

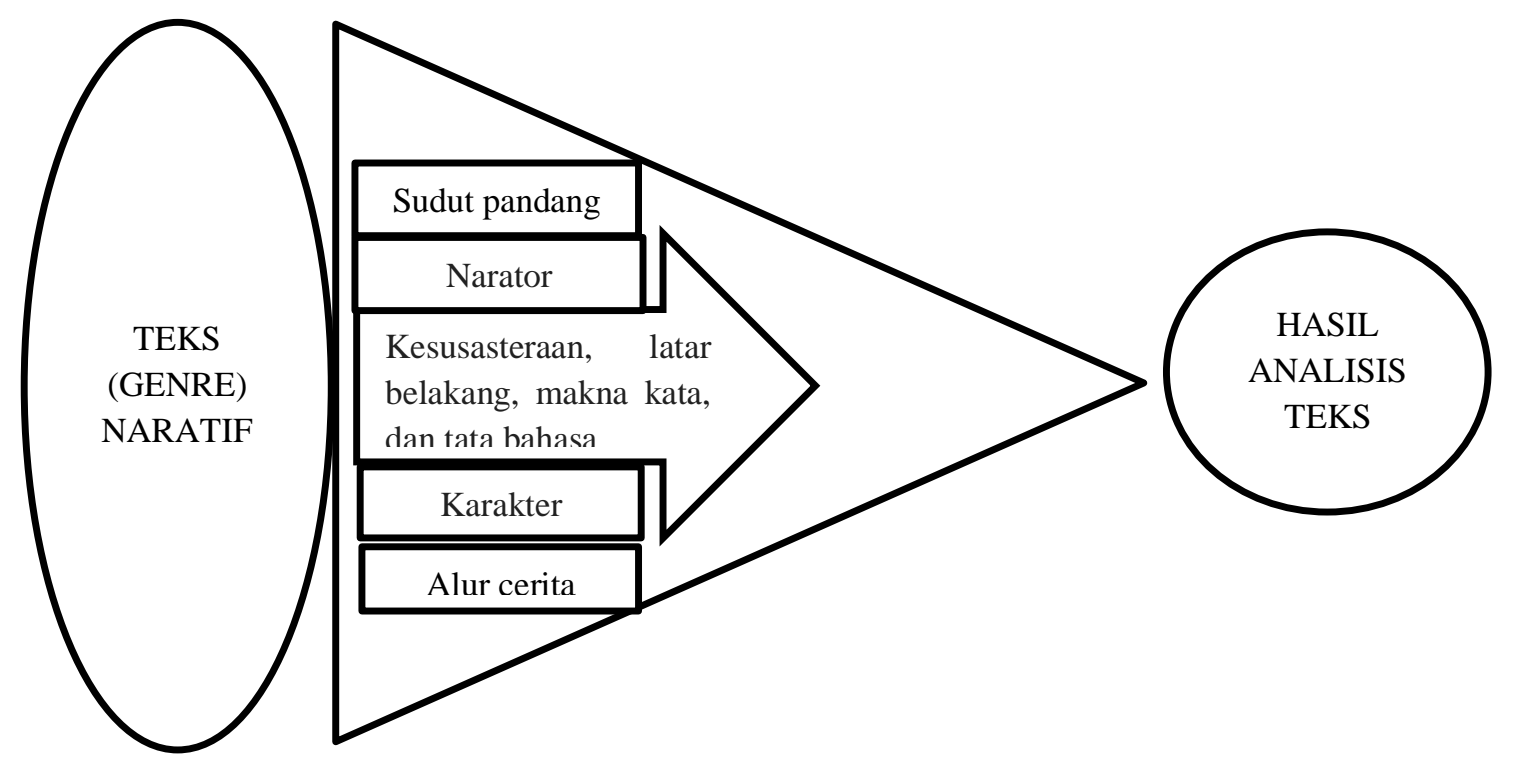

Gambar 1: Pendekatan Teks (genre) Naratif

${ }^{14}$ Adele Berlin, Poetics and Interpretation of Biblical Narrative (Sheffield: Sheffield Academic Press, 1997), 111.

${ }^{15}$ Mary H. Schertz and B. Perry Yorder, Exegesis for Students of Greek and Hebrew (Nashville: Abingdon Press, 2001), 16. 
Hal yang menjadi perhatian analisis naratif adalah unsur-unsur teks yang berkaitan dengan alur (plot), penokohan (karakter), sudut pandang (point of view) yang digunakan oleh seorang narator. Dengan demikian, melalui metode analisis naratif peneliti melihat teks sebagai sebuah "cermin" yang memproyeksikan gambaran tertentu, yaitu dunia narasi yang memberikan manfaat untuk mengeksplorasi bentuk dan unsur satire teks prolog dan epilog dari kitab Yunus.

\section{HASIL DAN PEMBAHASAN}

\section{Karakteristik Satire dalam Prolog Yunus 1}

\section{Narator}

Narator dalam pasal 1 tampil sebagai orang ketiga yang maha tahu (omniscient narrator) terhadap segala sesuatu yang terjadi di sepanjang cerita. ${ }^{16}$ Kehadiran narator yang maha tahu lebih cenderung memperlihatkan cerita dari pada menceritakannya. Hal ini terlihat dari interaksi para tokoh yang terlibat dalam dialog, Yunus dengan Tuhan dan Yunus dengan para awak kapal Melalui dialog ini, ditunjukkan karakter mereka, namun narator tidak memberikan penilaian terhadap mereka. Narator memberikan informasi "inner life" para awak kapal (ayat 5a, 10, 16), Tuhan (ayat 6b, 14b), Yunus (ayat 9, 12b). Narator menggunakan "inner life" untuk dapat menampilkan konflik di antara tokoh dan membiarkan pembaca untuk mengidentifikasi lebih banyak terhadap para tokoh. Bahkan melalui sudut pandang, narator mengarahkan pembaca untuk antipati terhadap Yunus. Kemahatahuan narator terbaca dari alur ceritanya yang diawali dengan penolakan Yunus dari panggilan Tuhan dan diakhiri dengan Yunus ditelan ikan besar.

Dalam pasal 1 narator menampilkan nilai artistik melalui penggunaan fitur retorika yang menunjukkan karakteristik satire dalam Yunus 1. Gaya bahasa personifikasi dan ironi mendominasi Yunus 1. Pemakaian gaya bahasa personifikasi untuk "menghidupkan" benda-benda mati seperti kapal, laut, angin, mengamuk (ayat 4, 11-13,15). Gaya bahasa personifikasi didominasi oleh gambaran laut sebagai subyek yang bergerak bahkan mengamuk dalam wujud badai besar (ayat 11-13,15). Akibatnya, kapal juga dipersonifikasikan: "dan kapal itu telah berulang-ulang berpikir untuk menjadi hancur" (1:4). Kata שָׁِר (shavar) umumnya dikenakan untuk Tuhan dan manusia sehingga ketika dikenakan kepada kapal, itu harus dipahami sebagai bahasa figuratif. ${ }^{17}$ Pemakaian konjugasi Piel הi:ׁنיָר (hishavar) memiliki pengertian intensif karena digambarkan dalam kondisi pertimbangan mengingat situasi yang kritis dan belum dalam kondisi akhir, yaitu hancur. Jadi pemakaian bentuk figuratif dengan memersonifikasikan kapal dengan manusia yang berpikir berulangulang untuk hancur menunjukkan "kepekaan", ${ }^{18}$ alam terhadap kemarahan Yang Maha Kuasa. Kata "kepekaan" tidak boleh dipahami sebagai nuansa emosional belaka karena

\footnotetext{
${ }^{16}$ Adji A. Sutama, Mengapa Kamu Menengadah Ke Langit: Analisis Naratif Kisah Kenaikan Yesus (Jakarta: BPK Gunung Mulia, 2000), 55.

${ }^{17}$ Francis Brown, S. R. Driver, and Charles A. Briggs, Hebrew and English Lexicon of the Old Testament (Oak Harbor, 1996), 363.

18،Holladay Hebrew Lexicon’ (BibleWorks LLC).
} 
menurut kata שַָָׁ (syafar) dalam bentuk konjugasi Piel menunjukkan seseorang yang merencanakan sesuatu bahkan melakukan kalkulasi. Ini menunjukkan sesuatu yang dipikirkan matang-matang. ${ }^{19}$ Kontras dengan Yunus di ayat 5. Ia memilih untuk tidur dan tidak melakukan respons apa pun terhadap bahaya yang terjadi. Perilaku Yunus yang konyol terkesan ganjil dikontraskan 'kalah' peka dengan benda mati (kapal), menunjukkan ironi dramatis.

Selain itu, juga ditemukan pemakaian gaya bahasa repetisi (pengulangan) demi mempertegas maksud narator: kata 'bangkitlah' (ay. 2) dan 'tetapi dia telah bangkit' (ay. 3) menunjukkan tindakan yang sama namun berlawanan, yang mempertegas tindakan Yunus yang berlawanan dengan kehendak Tuhan. Kata 'menjatuhkan' dalam ayat 7 diulangi beberapa kali semacam analogi tentang apa yang akan terjadi pada Yunus; dan frasa '...laut menjadi tenang, keluar dari tindakan melawan ...' (ayat 11 dan 12) menegaskan solusi badai yang menimpa mereka hanyalah melalui ketaatan Yunus untuk kembali kepada Tuhan. Ia harus berhenti 'keluar dari hadapan Tuhan.' Tentunya ini menjadi ironi dramatis dari tindakan Yunus yang berlawanan dengan kehendak Tuhan. Sejumlah hiperbola juga terkait dengan ironi: penyebutan kata sifat besar לạ (gadol), sebagai keterangan terhadap kota Niniwe (Yun. 1:2; bnd. 3:2), angin badai $(1: 4,12)$, dan ikan $(1: 17) .^{20}$

\section{Penokohan}

Karakteristik tokoh dapat dilihat melalui dialog para tokoh: Pertama, Yunus dan Tuhan (ayat 1-3). Di sepanjang pasal 1 ini ditemukan sangat sedikit dialog antara Tuhan dan Yunus. Tuhan berfirman dan memberikan perintah berseru dan 'bangunlah' (rise, RSV), dalam bahasa Ibraninya קום (qum)adalah kata kerja yang disebut sebagai 'inceptive force' atau untuk menunjukkan bahwa tindakan yang diperlukan harus segera dilakukan. ${ }^{21}$ Bagi Yunus perintah itu harus segera dilakukan, alasannya kejahatan Niniwe (bnd 3:2, 4 dan $8 b)$, perintah yang tidak dapat ditunda.

Faktanya Yunus menolak dan melarikan diri ke Tarsis. Tindakan konyol ini dipersepsikan negatif dari namanya Yona, יוֹנָנה berarti "merpati. Nama ini digunakan secara harifiah untuk menciptakan karikatur yang menghancurkan kredibiltas Yunus sebagai seorang nabi (Bolin, 1997:71). Ironi berasal dari nama Yunus itu sendiri karena dia

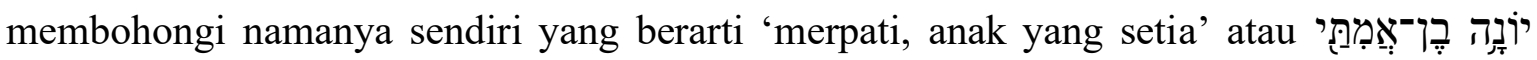

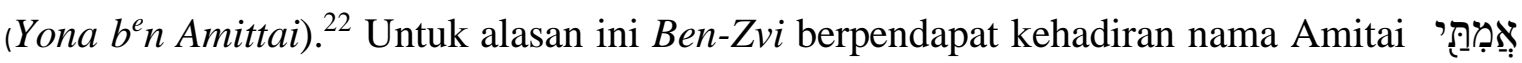
(amittati)di awal cerita memberikan petunjuk untuk nada satire atau ironi yang akan dikembangkan dalam kitab ini. ${ }^{23}$ Dari sudut pandang sastra, ironi adalah suatu acuan yang ingin mengatakan sesuatu dengan makna atau maksud berlainan dengan apa yang terkandung dari rangkaian kata-katanya. Pendapat lain mengatakan ini adalah sejenis gaya

${ }^{19}$ 'Holladay Hebrew Lexicon'.

${ }^{20}$ Douglas Stuart, 'The Great CIty of Niniweh (Jo. 1:2', Bibliotheca Sacra 171, 171 (2014), 391.

${ }^{21}$ Brymor F. Price and Eugene A. Nida, A Handbook of Jonah (New York: Harper and Row, 1978),

51.

${ }^{22}$ Wayne C. Booth, A Rhetoric of Irony (Chicago: Universiry of Chicago, 1974), 53.

${ }^{23}$ Ehud Ben Zvi, 'Signs of Jonah: Reading and Rereading in Ancient Yehud', Journal for the Study of The Old Testament Supplement Series, 367 (2003), 20. 
bahasa yang mengimplikasikan sesuatu yang nyata berbeda, bahkan sering kali bertentangan dengan sebenarnya dikatakan itu. Usaha Yunus untuk melarikan diri dapat dibaca sebagai ironi yang dramatis, kontradiksi implisit antara apa yang dikatakan atau dilakukan oleh seorang tokoh dan apa yang diketahui pembaca sebagai hal yang benar.

Karakter Allah yang berdaulat dengan jelas digambarkan dalam Yunus 1, khususnya melalui pemakaian bentuk kausatif yang menekankan Allah sebagai sumber terjadinya badai, bukan dewa laut. ${ }^{24}$ Karakter Allah yang berdaulat berpadu dengan sifat Allah yang universal, yang tergambar dalam ungkapan Yunus bahwa dia percaya pada YHWH, Pencipta laut dan darat, yang tertulis pada ayat 9. ${ }^{25}$ Untuk menjadi Tuhan yang memiliki kekuatan kosmis tidak perlu banyak dewa, cukup Yahweh saja. John Walton dalam hal ini berkomentar "dalam pengakuan Yunus, Yahweh diidentifikasikan sebagai mengungguli Baal dan Yamm."

Kedua, Yunus dan Para awak kapal dalam Badai Tuhan (ayat 4-16). Ketegangan Yunus dengan Tuhan berdampak pada awak kapal. Tuhan menurunkan badai yang mengakibatkan ketakutan bagi para awak kapal, sementara Yunus tertidur. Nakhoda kapal membangunkan Yunus, "Bangunlah, berserulah..." (ayat 6) adalah sebuah ironi verbal bernada teguran yang mengingatkan akan firman Tuhan kepada Yunus (1:2). Firman yang mengusik kehidupan Yunus terulang kembali lewat ucapan nakoda yang mengusik tidurnya. Nakhoda yang membangunkan Yunus dan memintanya berdoa bersama-sama dengan seluruh orang di kapal adalah sebuah ironi. Seorang nabi Tuhan harus didorong oleh seorang kafir untuk melakukan kegiatan religius - yaitu berdoa. ${ }^{26}$

Jawaban Yunus di ayat 9 menandai turning point (pembalikan arah) dari keseluruhan kisah di pasal 1, mengakui orang Israel dan mengakui kedaulatan Tuhan atas kosmis. Akan tetapi jawaban Yunus tersebut pada akhirnya menjadi ironi dramatis bagi dirinya. Pengetahuan teologisnya yang baik tidak disertai dengan ketaatan. Ironi dramatis terhadap jawaban Yunus tersebut juga terlihat dari penulis kitab yang menyematkan status takut akan Tuhan kepada para awak kapal (1:16).

Karakter para awak kapal sungguh unik. Mereka menjadi sindiran bagi Yunus karena etika para awak kapal itu lebih baik daripada Yunus. Mereka masih mengusahakan cara untuk menyelamatkan Yunus, sementara Yunus tidak ada usaha sama sekali untuk menyelamatkan Niniwe. Saat ini para awak kapal mengarahkan doa mereka kepada Yahweh, Tuhan Israel dan mempersembahkan korban dan bernazar (ayat 14,16). Brent A. Strawn berpendapat bahwa perkembangan tindakan religius para awak kapal merupakan sebuah sindiran bagi Yunus. Para awak kapal pada akhirnya mendatangi Tuhan sementara Yunus lari dari-Nya. Demikian juga penduduk Niniwe melakukan tindakan pertobatan yang lazim dilakukan di Israel: berdoa dan berpuasa. ${ }^{27}$

\footnotetext{
${ }^{24}$ J. Gordon McConville, Exploring the Old Testament Vol. 4 (Downers Grove: IVP, 2002), 192.

${ }^{25}$ McConville, 209. Band. Carl J. Bosma, 'Jonah 1:9 - An Example of Elenctic Testimony', Calvin Theological Journal, 48.1 (2003).

${ }^{26}$ Billy K. Smith and Frank S. Page, The New Commentary: Amos, Obadiah, Jonah (Nashville: Broadman \& Holman, 2001), 231.

${ }^{27}$ Brent A. Strawn, 'Jonah 's Sailors and Their Lot Casting : A Rhetorical-Critical Observation', Biblica, 91.1 (2010), 66-76.
} 


\section{Sudut Pandang (Point Of View)}

Dalam pasal 1 Yunus digambarkan sebagai pribadi yang pasif. Kepasifan Yunus terlihat dari sedikitnya porsi yang diberikan terhadap dialog Yunus. Hampir semua tindakan Yunus dalam pasal 1 adalah pasif. Ia tertidur sementara Tuhan aktif mengirimkan badai dan para awak kapal mencoba menyelamatkan nyawa mereka (Yun 1:5). Nakhoda pun harus membangunkannya dan memberitahukan kepada Yunus apa yang harus dilakukannya supaya selamat (1:6). Yunus kedapatan bersalah melalui undian (1:7-8). Kemudian Yunus memberikan solusi yang mana dirinya pasif sementara pelaut yang harus bertindak mengikat dirinya dan membuangnya ke laut $(1: 12,15)$.

Tindakan Yunus yang konyol menimbulkan kelucuan bagi pembaca, menjadikan dirinya sebagai obyek atau target untuk disindir. Humor ditampilkan melalui kontras perilaku Yunus dibandingkan dengan para awak kapal. Narator menggunakan perangkat sastra ironi untuk mendeskripsikan satire melalui peran para tokoh yang terlibat. Sikap pasif Yunus dibandingkan dengan para awak kapal pada akhirnya memberikan kesimpulan adanya sindiran bagi Yunus. Dengan segala perangkat literatur yang ada dalam pasal satu para pembaca diajak untuk bersikap antipati terhadap sang nabi.

\section{Alur Cerita (Plot)}

Berikut ini adalah plot pasal 1

Tabel 1: Alur Cerita (Plot) Pasal 1

\begin{tabular}{|l|l|}
\hline $\begin{array}{l}\text { Sikap penolakan Yunus dan } \\
\text { terjadi konfik (ayat 1-5) }\end{array}$ & Introduksi Narasi (ayat 1) \\
\cline { 2 - 2 } & $\begin{array}{l}\text { Pengantar narrator: ayat 2-3 } \rightarrow \text { Yunus menolak dan melarikan diri } \\
\text { ke Tarsis }\end{array}$ \\
\cline { 2 - 2 } $\begin{array}{l}\text { Konflik diselesaikan } \\
\text { (ayat 7-12, 15-16) }\end{array}$ & Pengantar narrator : badai besar, awak kapal dan Yunus (ayat 4-5) \\
\cline { 2 - 2 } & Yunus diinterogasi (ayat 8-10) \\
\cline { 2 - 2 } & $\begin{array}{l}\text { Yunus Yunus menyerah dan minta dilemparkan ke laut (ayat 11- } \\
\text { 12) }\end{array}$ \\
\cline { 2 - 2 } & $\begin{array}{l}\text { Pengantar narator : laut mereda dan para awak kapal } \\
\text { mempersembahkan korban pada Tuhan (ayat 15-16) }\end{array}$ \\
\hline $\begin{array}{l}\text { Sikap Yunus yang tidak } \\
\text { memahami peran ikan }\end{array}$ & $\begin{array}{l}\text { Pengantar narator : Yunus tinggal di perut ikan selama tiga hari } \\
\text { (ayat 17) }\end{array}$ \\
\hline
\end{tabular}

Berdasarkan plot tersebut dapat disimpulkan beberapa hal : Pertama, setiap adegan dimulai dengan sebuah pengantar dari narator. Kedua, setiap tokoh diberikan panggung untuk menunjukkan siapa mereka. Misalnya Yunus tokoh yang pasif, tertidur sementara Tuhan aktif mengirimkan badai dan para awak kapal mencoba menyelamatkan nyawa mereka (ayat 4-7). Kontras sikap Yunus dan para awak kapal menyebabkan Yunus sebagai target sindiran. Ketiga, alur cerita dimulai dari ironi sikap Yunus yang menolak panggilan Tuhan dan berakhir dengan sikap Yunus yang tidak memahami peran ikan.

\section{Karakteristik Satire Dalam Epilog Yunus 4}

\section{Narator}

Kehadiran narator yang maha tahu lebih cenderung memperlihatkan cerita dari pada menceritakannya. Hal ini terlihat dari interaksi para tokoh yang terlibat dalam dialog Yunus dengan Tuhan. Melalui dialog ini, ditunjukkan karakter mereka. Narator memberi- 
kan informasi "inner life" Yunus (ayat 1, 6b, 9b, 10), Tuhan (ayat 4,9a,11). Narator menggunakan "inner life" ini disajikan sedemikian rupa untuk menekankan kedalaman kasih Yunus dan Tuhan terhadap Niniwe. Hal ini terbaca melalui prolog ayat 1 dibuka dengan intensifikasi emosi kemarahan Yunus. Secara literal Yunus 4:1 dapat diterjemahkan sebagai berikut, “...hal tersebut adalah jahat רע ( $r a^{\prime}$ ) bagi Yunus dengan sangat jahat רָעָה (ra'ah). Dalam teks ini terdapat sebuah permainan kata (paronomasia) antara רעו (be evil, bad) dengan רָָָ (be evil, calamity) yang berfungsi sebagai sebuah intensifikasi ${ }^{28}$, sehingga terjemahannya dapat diparafrasakan sebagai berikut, “...hal tersebut sebuah kejahatan (atau kekesalan/malapetaka) yang besar, [lalu ia marah tentang hal ini].”

Intensifikasi paranomasi di atas menunjukkan dua buah ironi. Pertama, Yunus kesal sedangkan Yahweh bersukacita. Leslie C. Allen berkomentar bahwa "bom penghukuman" Tuhan yang diletakkan Yunus di Niniwe gagal meledak sehingga ia sangat kesal. ${ }^{29}$ Kedua, Tuhan membenci kejahatan, sehingga berbalik dan meninggalkan kejahatan adalah tujuan yang dikehendaki oleh Tuhan. ${ }^{30}$ Sebaliknya Yunus membenci pertobatan (bnd 1:2, kata ra'ah dikenakan pada Niniwe sedangkan 4:1 kata ra'ah dikenakan kepada pertobatan Niniwe). Kemahatahuan narator juga terbaca dari alur ceritanya yang diawali dengan kemarahan Yunus dan diakhiri dengan pertanyaan retoris Tuhan untuk mengoreksi sikap Yunus. Di pasal 4 narator menyimpulkan bahwa Tuhan mengendalikan segalanya dan bebas untuk memerintah tidak hanya unsur-unsur alam tetapi juga nabi, bebas untuk menubuatkan hukuman yang akan datang, dan bebas juga untuk mengubah rencana. Hal ini ditandai dengan frase "atas penentuan Tuhan" (ayat 6-8) dan semua obyek yang digunakan (pohon jarak, ulat, angin Timur) adalah pembawa aktual dari sudut pandang ideologi.

\section{Penokohan}

Karakteristik tokoh dapat dilihat melalui dialog para tokoh. Pertama, doa Yunus kepada TUHAN (ayat 2-3). Formulasi doa Yunus dengan sebuah seruan, "Ya TUHAN..." (Yun. 4:2) mirip dengan doa para awak kapal, "Ya TUHAN, Allah Israel..." (1:14). Terdapat sebuah ironi, di mana para awak kapal berdoa memohon kelepasan dari kematian, namun Yunus meminta supaya dirinya mati saja. Dalam doa Yunus terkait alasan mengapa ia melarikan diri ke Tarsis disebabkan belas kasihan Tuhan atas Niniwe. ${ }^{31}$ Di akhir doa Yunus, 'Engkaulah Yahweh yang pengasih dan penyayang, yang panjang sabar dan berlimpah kasih setia serta yang menyesal karena malapetaka yang hendak didatangkan-Nya.' Doa tersebut merupakan formulasi pengakuan iman Israel terhadap sifat Yahweh (Kel. 34:6; Bil. 14:18; Neh. 9:17; Mzm. 86:15; 103:8; 111:4; 112:4; 116:8; Yl. 2:13; Nah. 1:3; 2Taw. 30:9). Menurut Smith dan Page penggunaan formulasi tersebut oleh Yunus adalah sebuah sarkasme, sebagai ungkapan kemarahan. Sungguh ironis pernyataan teologis yang benar digunakan untuk membenarkan diri sendiri, dan bukan untuk tunduk kepada Tuhan. ${ }^{32}$

\footnotetext{
${ }^{28}$ Francis Brown, S. R Driver, and Charles A. Briggs, The Enchanced Brown-Driver-Briggs Hebrew and English LExicon (Oak Harbor, 2000), 949.

${ }^{29}$ Leslie C. Allen, Joel, Obadiah, Jonah, and Micah (Grand Rapids: Eerdmans, 1976), 227.

${ }^{30}$ Gernaida K.R. Pakpahan, 'Telusur Karya Ruakh (Roh) Dalam PErjanjian Lama', Diegesis: Jurnal Teologi, 4.2 (2019) <https://doi.org/https://doi.org/10.46933/DGS.vol4i21-14>.

${ }^{31}$ Meir Stenberg, The Poetic of Biblical Narrative: Idoelogical LIterature and The Drama of Reading (Bloomington Indiana University Press, 1985). 318.

${ }^{32}$ Smith and Page, The New Commentary: Amos, Obadiah, Jonah, 273.
} 
Permintaan Yunus kepada Tuhan untuk mencabut nyawanya merupakan ironi dramatis dari doanya di dalam pasal 2. Permintaan Yunus kepada TUHAN untuk mencabut nyawanya mirip dengan yang diucapkan oleh Elia, "Ambillah nyawaku" (1Raj. 19:4). Hal ini adalah sebuah parodi yang sengaja dibuat oleh penulisnya. ${ }^{33}$

Kedua, jawaban Tuhan terhadap doa Yunus. Jawaban Tuhan berupa pertanyaan bertujuan untuk mengoreksi paksa pemikiran Yunus. ${ }^{34}$ Meskipun merupakan pertanyaan korektif, penulis kitab Yunus secara konsisten menampilkan Yahweh yang berbelas kasihan.

Ketiga, doa ketidakpuasan Yunus kepada Yahweh (4:8b-9). Bentuk infinitive hiphil dari kata kerja dasar טוב (tov) 'to be good,' dan dalam bahasa Indonesia: "layakkah") dalam pertanyaan Tuhan dan jawaban Yunus, ${ }^{35}$ berfungsi menekankan kata keterangan (adverb) dari kata kerja yang didahuluinya חרה (khara) 'to be angry'. Jawaban Yunus membuatnya tidak bisa berdalih lagi tentang hak Tuhan untuk mengasihi Niniwe. Frasa 'marah sampai mati' berarti marah yang tidak dapat lebih lagi. Jika Yunus sudah marah sampai kepada puncaknya (marah sampai mati) maka Tuhan juga mengasihi Niniwe sampai kepada puncaknya. Dalam hal ini Tuhan sedang bersiap-siap untuk menyindir Yunus. ${ }^{36}$

Kelima, pengajaran dari Tuhan kepada Yunus (ayat 10-11). Firman Tuhan kepada חוס (hus) sebagai sebuah ironi dramatis. Sebagaimana Yunus sayang kepada pohon jarak demikian pula Tuhan mengasihi penduduk Niniwe yang jauh lebih berharga daripada pohon tersebut. Niniwe menjadi obyek Tuhan untuk mengajarkan Yunus mengenai belas kasih-Nya yang meluas bahkan kepada para penindas dan kedaulatan atas ciptaan-Nya. Yunus menjadi target utama yang dikritik dan diharapkan melalui pelajaran yang di dapat membawa perbaikan atau perubahan.

\section{Sudut Pandang (Point Of View)}

Ada dua hal yang dapat disampaikan tentang sudut pandang dari Yunus 4. Pertama, penulis kitab menjadikan pasal ini sebagai sebuah narasi historis dengan gambaran yang hidup (vivid and sensational). Gambaran yang gamblang tersebut misalnya pohon jarak, ulat, dan angin kering sebagai alat pelajaran bagi Yunus (ay. 5-11). Gambaran-gambaran dalam Yunus 4 pada akhirnya menyediakan ironi terhadap diri Yunus. Ironi sikap Yunus dalam pasal 4 tersebut menggemakan ironi sikap Yunus dalam pasal 1. Dalam pasal 1 sikap yang diharapkan terjadi dari Yunus malah ditunjukkan oleh para awak kapal yang kafir. Dalam pasal 4 sikap yang diharapkan terjadi dari Yunus malah ditunjukkan oleh penduduk Niniwe. Ia telah dikoreksi oleh Tuhan sebelumnya namun tidak mau bertobat. Bahkan sejak diutus Tuhan ke Niniwe ia telah memahami natur Tuhan yang penuh belas kasihan (Yun. 4:2, band. 1:3). Lain halnya dengan Niniwe yang ditegur-Nya namun bertobat.

\footnotetext{
${ }^{33}$ The Minor Prophets, Job, Psalms, Proverbs, Ecclesiastes, Song of Songs: Zondervan Illustrated Bible Backgrounds Commentary of the Old Testament, ed. by John H. Walton (Grand Rapids: Zoncervan, 2009), 116.

${ }^{34}$ Douglas Stuart, Hosea-Jonah: World Biblical Commentary, 31st edn (Dallas: Word, 2002).

${ }^{35}$ Stuart, Hosea-Jonah: World Biblical Commentary, 500.

${ }^{36}$ Bruce K. Waltke and M. O'Connor, An Introduction to Biblical Hebrew Syntax (Winona Lake: Eisenbrauns, 2004), 269.

${ }^{37}$ Bruce K. Waltke and M. O’Connor, An Introduction to Biblical Hebrew Syntax, 209.
} 
Sebagai tambahan kebebalan Yunus juga nampak lewat permintaan yang tidak berubah. Ia meminta untuk mati daripada hidup (Yun. 4:3, 8).

Kedua, dominasi dialog Tuhan dengan Yunus. Narator seolah-olah mundur dan membiarkan kedua tokoh saling berdialog untuk menunjukkan sebuah pesan langsung tentang kasih Tuhan. Narator tidak banyak berkomentar dan setiap tokoh diberikan panggung untuk menunjukkan siapa mereka. Misalnya pembukaan oleh narator tentang Yunus yang marah ditunjukkan dengan doa Yunus kepada Tuhan di ayat 2-3. Karena itu pengajaran teologis diberikan oleh narator sebagian besar dalam bentuk orang pertama dan kedua (dialog Tuhan dan Yunus). Melalui dialog tersebut pembaca memperoleh pembelajaran tentang kasih Tuhan yang diberikan seturut kerelaan-Nya dan tidak ada seorang pun yang berhak memprotesnya (khususnya dalam ayat 10-11).

\section{Alur Cerita (Plot)}

Berikut ini adalah plot pasal 4:

Tabel 2: Alur Cerita (Plot) Pasal 4

\begin{tabular}{|l|l|}
\hline \multirow{2}{*}{$\begin{array}{l}\text { Kemarahan Yunus dan } \\
\text { Jawaban Tuhan (ayat 1-4) }\end{array}$} & Introduksi Narasi (ayat 1) \\
\cline { 2 - 2 } & Doa Ketidakpuasan Yunus (ayat 2-3) \\
\cline { 2 - 2 } & Jawaban Tuhan kepada Yunus (ayat 4) \\
\hline \hline \multirow{2}{*}{$\begin{array}{l}\text { Penutup: Obyek Pembelajaran } \\
\text { Langsung dari Tuhan }\end{array}$} & Pengantar Narator: Yunus dan Pohon Jarak (ayat 5-8a) \\
\cline { 2 - 2 } & Doa Ketidakpuasan Yunus (ayat 8b) \\
\cline { 2 - 2 } & Pengajaran Tuhan kepada Yunus tentang kasih-Nya (ayat 9-11) \\
\hline
\end{tabular}

Berdasarkan plot tersebut dapat disimpulkan beberapa hal. Pertama, setiap adegan dimulai dengan sebuah pengantar dari narator. Kedua, dialog antara Tuhan dengan Yunus memegang peranan penting. Melalui dialog ini Yunus disindir sebagai tokoh oposisi terhadap Yahweh. Oposisi tersebut tidak hanya dalam hal tindakan, tetapi terutama yang ditonjolkan adalah sifat keduanya. Tuhan adalah Pribadi yang mempunyai belas kasihan, sedangkan Yunus adalah pribadi yang tidak mempunyai belas kasihan. Sikap oposisi Yunus menunjukkan ironi dramatis terhadap dirinya sebagai seorang nabi. Dampaknya adalah tantangan kepada pembaca untuk memilih apakah mereka akan bersikap seperti Yunus, atau mereka memahami Tuhan sebagai Allah yang berbelas kasihan. ${ }^{38}$

\section{KESIMPULAN}

Penggunaan analisis naratif sebagai "vehicle" untuk menemukan bentuk dan karakteristik satire prolog dan epilog kitab Yunus. Bentuk satire yang menonjol adalah ironi terlihat dari awal pada saat Yunus menolak perintah Tuhan (Yun. 1:3) dan klimaksnya ketika Yunus memilih mati dari pada hidup (Yun. 4:8). Ironi mendasari semua unsur satire yang tersebar di pasal 1 dan 4. Dari rangkaian unsur narasi tersebut menunjukkan satire sebagai bagian dari gaya retorik atau perangkat sastra yang digunakan penulis untuk mengekspos dan mengkritisi Yunus dengan menggunakan ironi, personifikasi, hiperbola, repetisi, sarkasme, paronomosia dan parodi. Yunus menjadi target sindiran. Peneliti mengelompokkan unsur ironi adalah personifikasi, repetisi, hiperbola, sarkasme, paronomosia dan

${ }^{38}$ J. H Kenedy, Studies in the Book of Jonah (Nashville: Broadman, 1956). Band. Gerhard von Rad, The Messafe of the Prophets, ed. by D.M.G. Stalker (New York: Harper and Row, 1965). 
parodi. Karakteristik ini mengindikasikan prolog dan epilog kitab Yunus adalah narasi yang mengandung satire.

Kisah Yunus merupakan cerita yang sangat terkenal. Namun banyak orang salah mengingat hal-hal terpenting dari Kitab Yunus. Mereka lebih mengingat tentang ikan besar yang menelan Yunus dari pada mengingat pesan utama dari kitab itu: Tuhan yang berbelas kasihan dan berdaulat penuh atas ciptaan-Nya. Kitab Yunus mengandung kisah tentang kebencian, rasisme, dan intoleransi. Yunus, seorang nabi Israel, memberontak ketika Allah mengutusnya ke Niniwe, yang merupakan ibukota Asyur, musuh Israel. Walaupun Yunus berusaha melarikan diri dari panggilannya, namun Tuhan memimpinnya kembali. Walaupun demikian, hati Yunus tetap dipenuhi kebencian terhadap Niniwe. Ia tidak senang atas pertobatan dan terhindarnya Niniwe dari murka Allah. Kitab itu diakhiri dengan pertanyaan retorik Allah sendiri. Tidak diceritakan bagaimana respon Yunus: Apakah ia pada akhirnya bisa mengasihi penduduk Niniwe? Atau justru tetap membenci kota itu sampai pada akhir hidupnya?

\section{REFERENSI}

Allen, Leslie C., Joel, Obadiah, Jonah, and Micah (Grand Rapids: Eerdmans, 1976)

Berlin, Adele, Poetics and Interpretation of Biblical Narrative (Sheffield: Sheffield Academic Press, 1997)

Booth, Wayne C., A Rhetoric of Irony (Chicago: Universiry of Chicago, 1974)

Bosma, Carl J., 'Jonah 1:9 - An Example of Elenctic Testimony', Calvin Theological Journal, 48.1 (2003)

Brown, Francis, S. R. Driver, and Charles A. Briggs, Hebrew and English Lexicon of the Old Testament (Oak Harbor, 1996)

Brown, Francis, S. R Driver, and Charles A. Briggs, The Enchanced Brown-Driver-Briggs Hebrew and English LExicon (Oak Harbor, 2000)

Djuharto, Gumulya, 'ANALISA PANGGILAN YUNUS DALAM KITAB YUNUS 1 : 1 17', Jurnal Theologi Aletheia, 16.6 (2014), 1-17

Harkins, Robert Justin, 'Jonah and The Prophetic Character' (Vanderblit University, 2010)

Haughwout, Mark S., Humor in the Bible (Hebrew University Jerusalem, 2010)

'Holladay Hebrew Lexicon' (BibleWorks LLC)

Juliana, L., and M. Claassens, 'Rethinking Humour in the Book of Jonah: Tragic Laughter as Resistance in the Context of Trauma', Old Testament Essays, 28.3 (2015), 655-73 <https://doi.org/10.17159/2312-3621/2015/v28n3a6>

Kenedy, J. H, Studies in the Book of Jonah (Nashville: Broadman, 1956)

Limburg, James, Jonah: A Commentary (Kentucky: Westminster/John Konx Press, 1993)

Marcus, David, From Balaam to Jonah - Anti-Prophetic Satire in the Hebrew Bible (Atlanta: Scholar Press, 1995)

McConville, J. Gordon, Exploring the Old Testament Vol. 4 (Downers Grove: IVP, 2002)

McKenzie, Steven L., and Stephen R. Haynes, To Each Its Own Meaning: An Introduction to Biblical Criticisms and Their Application (Louisville: Westminster/John Konx Press, 1999)

Miles Jr., John A., 'Laughing at the Bible: Jonah as Parody', in On Humor and Comic in the Hebrew Bible (Sheffield: Almond Press, 1990)

Muryati, Yusak Setianto, Priskila Issak Benyamin, and Alex Frans Nathanael Nasution, 'Strategi Mengatasi Kemarahan Melalui Perumpamaan Berdasarkan Yunus 4', Jurnal Teologi Gracia Deo, 3.1 (2020), 14-23 
Pakpahan, Gernaida K.R., 'Telusur Karya Ruakh (Roh) Dalam PErjanjian Lama', Diegesis: Jurnal Teologi, 4.2 (2019) <https://doi.org/https://doi.org/10.46933/DGS.vol4i21-14>

Patterson, Richard D., 'Prophetic Satire As a Vehicle for Ethical Instruction', Journal of the Evangelical Theological Society, 50.1 (2007), 47-69

Price, Brymor F., and Eugene A. Nida, A Handbook of Jonah (New York: Harper and Row, 1978)

Rad, Gerhard von, The Messafe of the Prophets, ed. by D.M.G. Stalker (New York: Harper and Row, 1965)

Schertz, Mary H., and B. Perry Yorder, Exegesis for Students of Greek and Hebrew (Nashville: Abingdon Press, 2001)

Smith, Billy K., and Frank S. Page, The New Commentary: Amos, Obadiah, Jonah (Nashville: Broadman \& Holman, 2001)

Stenberg, Meir, The Poetic of Biblical Narrative: Idoelogical LIterature and The Drama of Reading (Bloomington Indiana University Press, 1985)

Strawn, Brent A., 'Jonah' s Sailors and Their Lot Casting : A Rhetorical-Critical Observation', Biblica, 91.1 (2010), 66-76

Stuart, Douglas, Hosea-Jonah: World Biblical Commentary, 31st edn (Dallas: Word, 2002) , 'The Great CIty of Niniweh (Jo. 1:2', Bibliotheca Sacra 171, 171 (2014)

Sutama, Adji A., Mengapa Kamu Menengadah Ke Langit: Analisis Naratif Kisah Kenaikan Yesus (Jakarta: BPK Gunung Mulia, 2000)

Vaillancourt, Ian J., 'The Pious Prayer of an Imperfect Prophet : The Psalm of Jonah in Its Narrative Context', Journal for the Evangelical Study of the Old Testament, 4.2 (2015)

Walker, Alyssa, 'Jonah' s Genocidal and Suicidal Attitude — and God' s Rebuke *', KAIROS - Evangelical Journal of Theology, 9.1 (2015), 7-30

Waltke, Bruce K., and M. O'Connor, An Introduction to Biblical Hebrew Syntax (Winona Lake: Eisenbrauns, 2004)

Walton, John H., ed., The Minor Prophets, Job, Psalms, Proverbs, Ecclesiastes, Song of Songs: Zondervan Illustrated Bible Backgrounds Commentary of the Old Testament (Grand Rapids: Zoncervan, 2009)

Zvi, Ben Ehud, 'Jonah', in The Jewish Study Bible, ed. by Berlin Adele and Marc Zvi Brettler (Oxford: Oxford University Press, 2004)

Zvi, Ehud Ben, 'Signs of Jonah: Reading and Rereading in Ancient Yehud', Journal for the Study of The Old Testament Supplement Series, 367 (2003) 